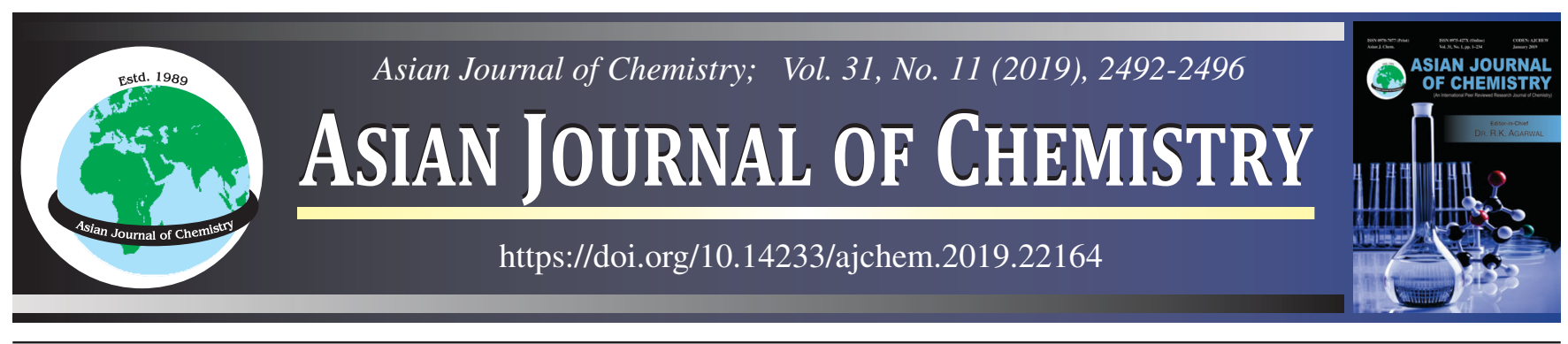

\title{
Morphological Changes Occurred During Long Time Atmospheric Corrosion Process of Mild Steel and their Effect on Mechanical Properties
}

\author{
P. Muralidhar ${ }^{1,2}$, G. Satyanarayana ${ }^{2, *}$ and G. Nageswara RaO ${ }^{2}$
}

${ }^{1}$ RINL, Visakhapatnam Steel Plant, Visakhapatnam-530031, India

${ }^{2}$ Department of Inorganic and Analytical Chemistry, Andhra University, Visakhapatnam-530003, India

*Corresponding author: E-mail: satya.bic@gmail.com

Received: 29 April 2019;

Accepted: 5 June 2019;

Published online: 28 September 2019;

AJC-19575

\begin{abstract}
The present work, involves the analysis of a long time corroded steel channel (MC 150 having dimensions $150 \mathrm{~cm} \times 75 \mathrm{~cm} \times 5.7 \mathrm{~cm}$, a nominal weight of $16.8 \mathrm{~kg} / \mathrm{m}$, which was rolled from a fully killed continuous cast steel blooms) meant for constructing huge steel structures was performed. The analysis of this typical corrosion was done in a different direction to know the morphological changes occurred during the long time atmospheric corrosion periods of wet dry conditions. The extent of deterioration of mechanical properties in these structural components may reduce the life span of particular component. The focus of this present study is to analyze the reasons for the splitting of corrosion product layers during the long time atmospheric corrosion conditions, which resulted in the drastic deterioration of mechanical properties. The XRD analysis of delaminated layers was also performed. The physico-chemical changes occurred in the process of long time atmospheric corrosion were also investigate. It is found that pitting is the major contributor for the formation, growth, delamination of corrosion product layers during the long time atmospheric corrosion process, which resulted in the drastic reduction of mechanical properties.
\end{abstract}

Keywords: Delaminated corrosion product, Rolling direction, Pit growth, Dissolution pattern.

\section{INTRODUCTION}

Steel is the most commonly employed metallic material in open-air structures and used to make a wide range of equipment and metallic structures due to its low cost and good mechanical strength. Most of the steel that is manufactured is exposed to outdoor conditions, often in highly polluted atmospheres where corrosion is much more severe than in clean rural environments $[1,2]$. Atmospheric corrosion is not a clearly defined process, as this corrosion of metallic structures occurs in various types of open atmospheric environments which is the most destructive type due to which major sudden failures occurring by the interaction of the metal with its surroundings, which causes internal damage to metallic structures, equipment [3]. Various factors viz. relative humidity, temperature, exposure time, salinity, sulphur content, time of wetness, presence of air pollutants, etc. are the major contributors for this type of corrosion.
Numerous researches on the atmospheric corrosion were done by several workers [1-6]. However, comparably less information is available on long time atmospheric corroded steel samples. As a common point in designing structural components, due to high stress state in a specific member may affect the fatigue life due to which fatigue failure is aggravated [7,8]. Fatigue failure mechanism of on reinforced concrete beams in a noncorrosive environment was studied by few researchers $[9,10]$. The typical environment where structural components like bridges operate are prone to frequent fatigue damage $[11,12]$.

Corrosion fatigue results in the degradation of mechanical properties of structural members exposed to corrosive environment [13]. Corrosive environment is mainly manifested by the cracking of the members due to corroded concrete. As a result, the reinforcement becomes corroded. Corrosion aggravates the defects like internal cracks induced by cyclic loading conditions and micro pits initiated due to crevice corrosion

This is an open access journal, and articles are distributed under the terms of the Attribution 4.0 International (CC BY 4.0) License. This license lets others distribute, remix, tweak, and build upon your work, even commercially, as long as they credit the author for the original creation. You must give appropriate credit, provide a link to the license, and indicate if changes were made. 
beneath the already formed corrosive layers at the surface which damages the bond between the metallic part and concrete in the huge constructions [14]. In long run, a number of problems occurring due to the deterioration of metallic component and its conversion to its stable oxide form. Metals exposed to uncontrolled normal atmospheres may corrode more rapidly by different mechanisms than those kept in pure dry air. Mild steel has versatile applications as structural components for construction of buildings, bridges, huge structural constructions, sky scrapers, underground pipelines, etc. Various types of steels like structural steels, rail steel were used to cater the needs in our dailylife. Mild steel is very much prone to corrosion in industrial and marine environments, having harmful pollutents and other industrial effluents in addition to normal humid atmosphere.

These corrosion problems are very much severe in a tropical country like india, having vast coastel line. There is a lack of basic research on the formation mechanisms and internal microstructure of these rust types. Basically how this long time corrosion will affect the internal metallic properties and reasons for the strength deterioration is also to be envisaged by analyzing the changes occurred in the corrosion product and the parent metal. Research conducted by Liu et al. [15] and Li et al. [16] in a steel strand resulted in strength degradation by the increase in corrosion and strength decreases by three quarters after 2.5 years of exposure.

The experimental results of an artificial climate simulation test and an electrochemical acceleration test conducted show a nonlinear relationship between the ultimate strength and corrosion rate of steel strands. Barton and Nakamura and others show that tension has little effect on steel corrosion, while several literature showed that strain levels can accelerate the corrosion rate of steel component [17-23].

\section{EXPERIMENTAL}

For assessing the internal mechanical properties various testing methods includes, yield strength (YS), ultimate tensile strength (UTS), percent elongation (\% El), etc. were done to long time atmospheric corroded steel, fresh steel and corroded steel. Sample preparation was done as per acc specification, by using UTM (MODEL:FIE-UTN-20T) and a comparative study was done to know the reasons for variation in mechanical properties. Both macro- and microscopic study was done to know the corrosion product morphology occurring during the long time corrosion process of this steel (Fig. 1a). Most of the materials used in construction are mild steels with some amount of alloy addition and proper heat treatment. The position of MC150 steel channel is kept in such a way that atmospheric moisture/rain water is stagnated above the channel which is placed on the ground due to stagnation of rain water (during the rainy season), drying of this component remaining periods, for a period of more than 20 years of atmospheric corrosion various morphological changes occurred resulted in delamination of corrosion product layers from the channel. By collecting corrosion product from the delaminated surface layers and intermediate layers where corrosion is still under progress and their dissolution in $3 \% \mathrm{NaCl}$ solution was monitored to know the extent of the progression of this corrosion reaction. A lot of interesting macroscopic features of corrosion product morphology were recorded by using (camera: leno-536). XRD analysis of individual layers of corrosion product (Fig. 1b) was also done by using PANalytical X'pert pro X-ray diffractometer at $2 \theta$ range of $10^{\circ}$ to $90^{\circ}$ using $\mathrm{Cu}-\mathrm{K} \alpha$ radiation $(\lambda=1.5405 \AA$ ).

\section{RESULTS AND DISCUSSION}

Macroscopic study: A specific and special observation noted down was that delamination of the corrosion product so formed was occurred in the direction where plastic deformation taking place during rolling (Fig. 2A). When compared to parent metal thickness, the layered structure thickness was 6 times (Fig. 2B). Even in the bent/mechanically damaged portion the splitting of corrosion product layer is following the same pattern as in straight channel (Fig. 2C). Grouping, growing of pits at localized area and the colour change near the pits were also observed (Fig. 2D). Replicas of pitting observed in each successive layer and as a whole were observed in both samples (Fig. 2E and 2F) from the top and bottom portions of the delaminated corrosion product layer. Fig. $2 \mathrm{E}$ is the bottom portion of delaminated layer (near to metallic surface) having various colour changes at the replicas of pit, top portion of the same corrosion product layer is having projected corrosion products (Fig. 2F) from pit zone. Tensile test specimen (Fig. 2G) showed almost no elongation. Severe pitting was observed at the tensile specimen after the complete removal of adherent rust (Fig. 2H).

Microscopic study: Cross section of the intermediate zone of corrosion was microscopically observed by using optical microscope (model Lica, DM 16000M).

Clear cut demarcation was observed in the zone of corrosion indicating up to certain distance in the longitudinal direction, a grey coloured corrosion product layer observed and the remaining zone white portion indicating mild steel micro structure i.e. ferrite and pearlite (Fig. 3A). Micro level splitting

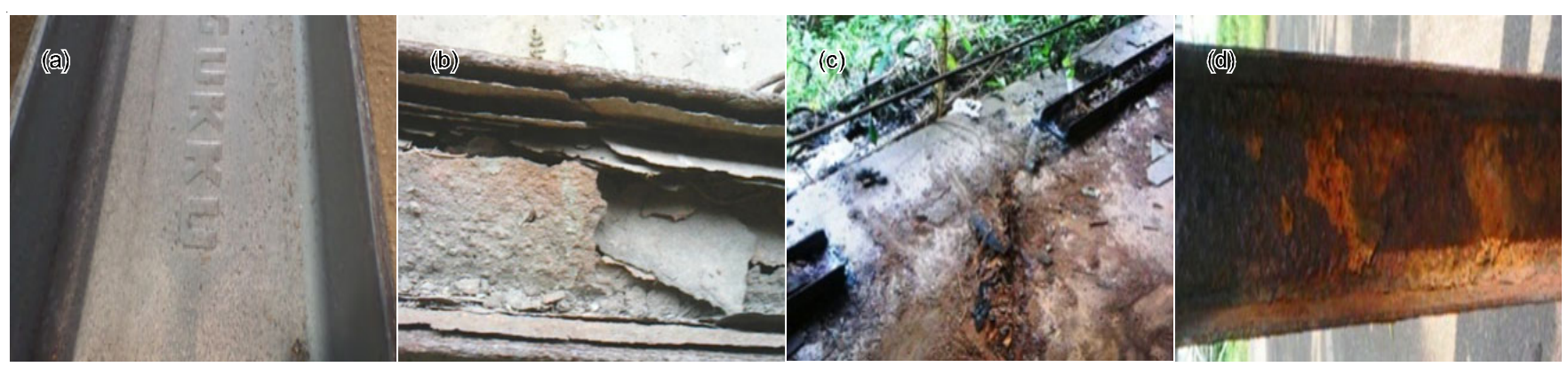

Fig. 1. Channel under atmospheric corrosion (a) new channel [MC150]; (b) delaminated layers of channel [MC150] after 26 years of atmospheric corrosion; (c) sampling location; and (d) channel after removal of rust layers 

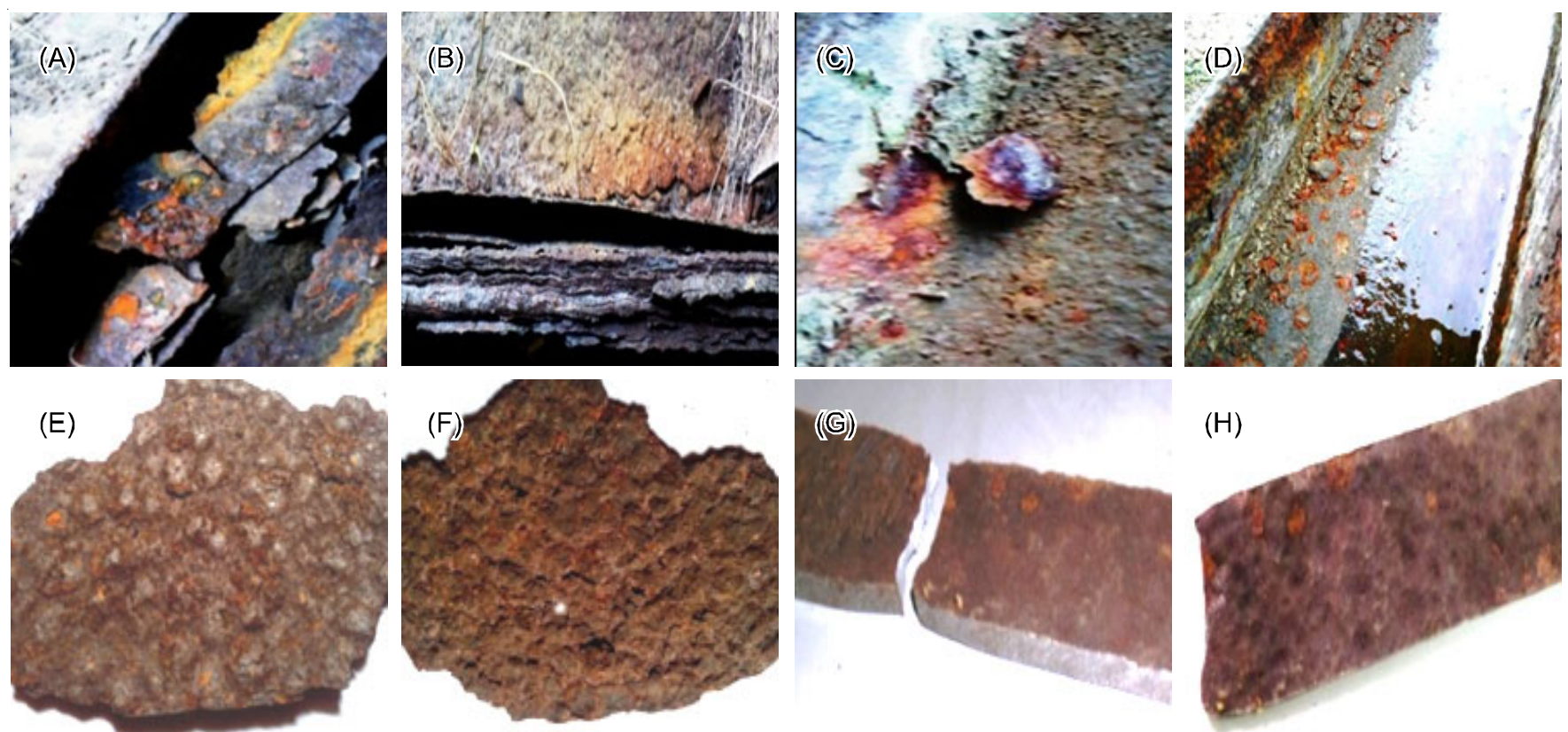

Fig. 2. Macroscopic observation of long time corroded channel and its corrosion product
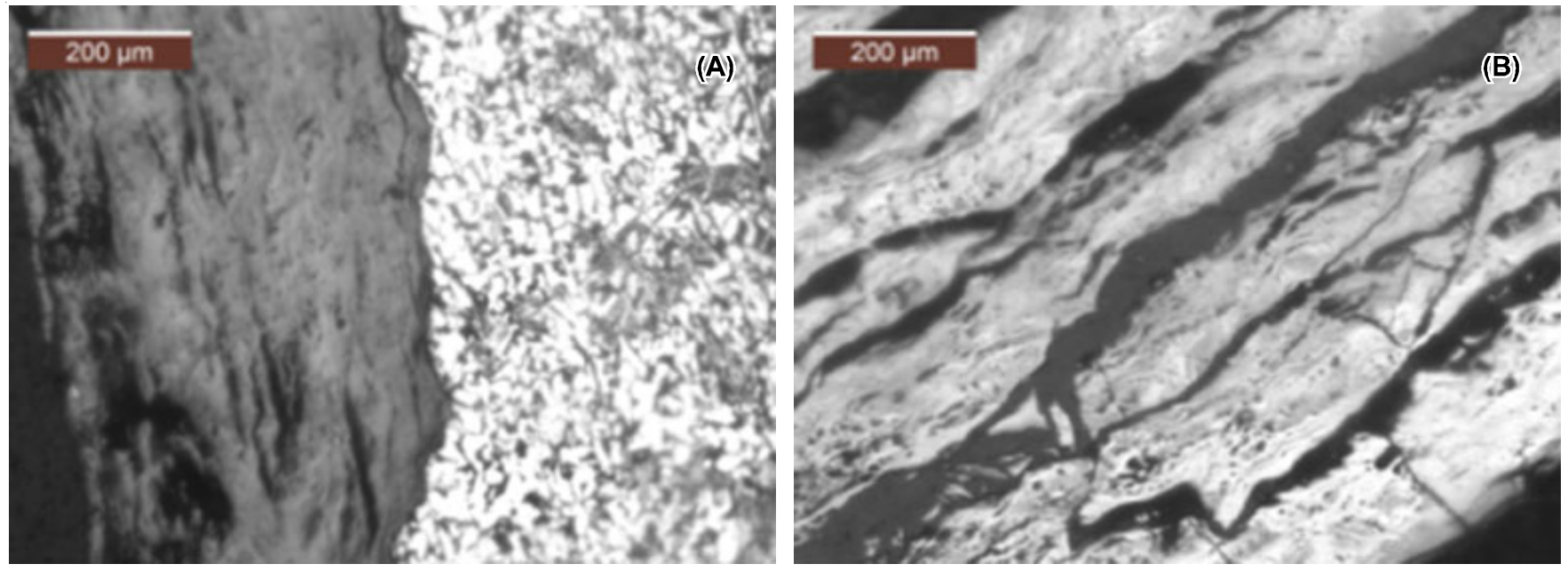

Fig. 3. Microscopic observation of long time corrosion product
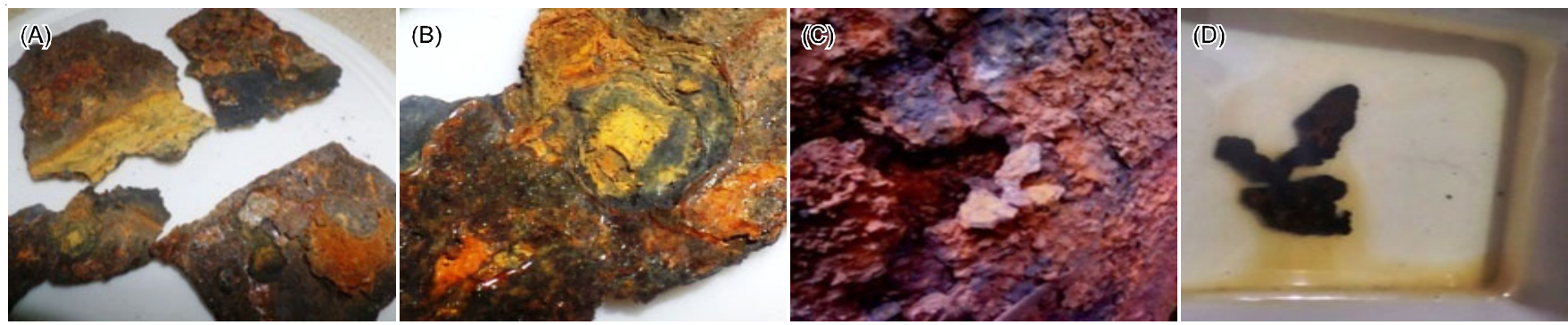

Fig. 4. Dissolution process of corrosion product layers collected in different zones of corrosion of $\mathrm{MC} 150 \mathrm{channel}$ in $3 \% \mathrm{NaCl}$ solution

in corrosion product layers (Fig. 3B) also observed at the cross section. The grey coloured corrosion product also having splits, micro cracks. Far away from the corroded zone no abnormality in the micro structure.

Long time corrosion product not at all dissolved in $3 \%$ $\mathrm{NaCl}$ solution (Fig. 4A) where as in intermediate corrosion product collected from the middle of the zone of corrosion under progress (Fig. 4C and 4D), at locations dissolution process started indicating still some amount of metal is in intermediate stage of corrosion. The replicas of pitting in the form of concentric coloured circles on the corrosion product (Fig. 4B) observed, which was also not dissolved in $3 \% \mathrm{NaCl}$ solution. The corrosion product layers so formed are fragile in nature and composed of localized corrosion product growth. In intermediate zone of the corrosion still metallic nature observed by the localized dissolution of these collected corrosion product in $3 \% \mathrm{NaCl}$ solution, colour change at locations also observed indicating progression of corrosion by the internal formation of pits. XRD 
TABLE-1

COMPARATIVE XRD ANALYSIS OF LONG TIME CORROSION PRODUCTS OF CHANNEL

\begin{tabular}{|c|c|c|c|c|}
\hline \multirow{2}{*}{ hkl } & \multirow{2}{*}{ Magnetite d A/2 $\theta / \mathrm{I} / \mathrm{I}$} & MCL-1 d A/2 $\theta / \mathrm{I} / \mathrm{I}$ & MCL-2 d A/2 $\theta / I / I$ & MCL-3 d A/2 $2 / / / \mathrm{I}$ \\
\hline & & $6 \mathrm{~A}$ & $6 \mathrm{~B}$ & $6 \mathrm{C}$ \\
\hline 220 & $2.96 / 30.32 / 29$ & $2.99 / 29.81 / 23.82$ & $2.97 / 29.99 / 31.65$ & $2.99 / 29.84 / 25.49$ \\
\hline 311 & $2.52 / 35.3 / 100$ & $2.54 / 35.17 / 100$ & $2.53 / 35.38 / 100$ & $2.54 / 35.27 / 100$ \\
\hline 400 & $2.09 / 43.32 / 20$ & $2.09 / 42.9 / 24.00$ & $2.09 / 43.04 / 25.39$ & $2.10 / 42.90 / 23.31$ \\
\hline 422 & $1.71 / 53.89 / 8$ & - & - & - \\
\hline 511 & $1.61 / 57.34 / 24$ & $1.61 / 56.89 / 21.11$ & $1.61 / 57.05 / 27.08$ & $1.61 / 56.84 / 30.62$ \\
\hline 440 & $1.48 / 62.96 / 34$ & $1.48 / 62.60 / 34.60$ & $1.48 / 62.54 / 46.15$ & $1.48 / 62.6 / 35.09$ \\
\hline
\end{tabular}

spectra of the successive delaminated layers showing magnetite crystal structure along with some other minor peaks of other oxides (Fig. 5). Major peaks observed were compared with JCPDS: 893319. Most intense lines [311] and [440] confirms magnetite indicating that the comparative $2 \theta$ peaks at $35.4^{\circ}$ and $62.86^{\circ}$ were almost matched with magnetite (Table-1). The comparative results of chemical analysis and mechanical properties are shown in Tables 2 and 3, respectively. As seen, slight variation was observed in all the elements of steel channel under normal corrosion, however, during long time corrosion process of steel, a decrease in composition is significant.

The inter-lamellar spacing d values, $2 \theta$ values, relative intensities $\mathrm{I} / \mathrm{I}_{0}$ all are almost matching with the XRD values of magnetite. Slight variation values of these delaminated corrosion product layers MCL1, MCL2 and MCL3, respectively (Table-1), which indicates that the process of this delamination occurred continuously at all zones, by cathodic delamination process. At the same time in the process of long time corrosion splitting occurred initially and propagating throughout the surface to subsurface layers, through which the water is transported continuously as there is a scope of stagnation of water in the channel due to its inclined position. Magnetite in all the delaminated corrosion product layers is observed indicative of the transformation of corrosion product layers was occurring in all the delaminated layers. Drastic change in mechanical properties of the steel component under long time atmospheric corrosion was observed these are not even in the minimum specified range. Main reason for the reduction in the properties variation is during long time corrosion process the reduction in actual thickness of the steel under corrosion. Additional important feature observed in case of long time corrosion process is the uniform pitting corrosion observed, which is shown as undulations on the long time corroded metal.

\section{Conclusion}

In long time corrosion process of mild steel macroscopic analysis of corrosion product layers formed at the zone of corrosion attack reveals various morphological changes like splitting and disjoining of corrosion product layers parallel to the rolling or shaping (mechanical deformation) direction of the steel component manufacturing process. Colour change variation in and around the pits formed at the zone of corrosion progression. The corrosion product layers so obtained are fragile in nature. Comparatively the layer away from the parent metal i.e. outer layer is more fragile than the corrosion product layer attached to the surface or near to surface. Thickness of
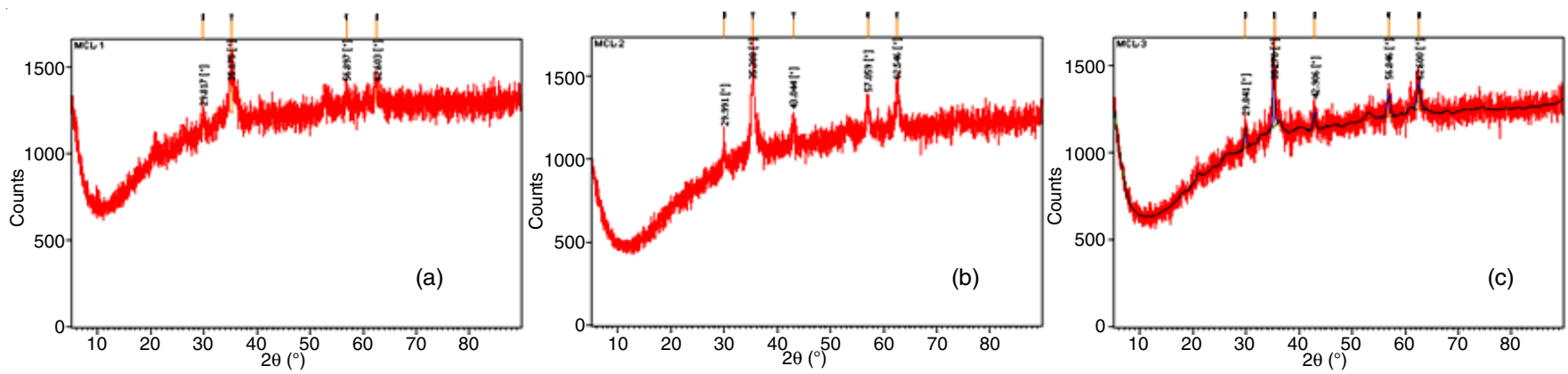

Fig. 5. XRD spectra of delaminated corrosion product layers of long time corroded MC150; (a) [MCL1]; (b) [MCL2]; (c) [MCL3]

\begin{tabular}{|c|c|c|c|c|c|c|}
\hline \multicolumn{7}{|c|}{$\begin{array}{c}\text { TABLE-2 } \\
\text { CHEMICAL ANALYSIS OF MC-150 CHANNEL }\end{array}$} \\
\hline Sample & $\mathrm{C}$ & $\mathrm{Mn}$ & $\mathrm{P}$ & $S$ & $\mathrm{Si}$ & $\mathrm{Al}$ \\
\hline MC-150 & 0.19 & 0.72 & 0.031 & 0.032 & 0.20 & 0.020 \\
\hline IS-2062 & $0.13-0.25$ & $0.3-1.5$ & 0.05 max. & $0.05 \max$. & 0.40 max. & 0.020 \\
\hline MC150-corroded & 0.18 & 0.64 & 0.026 & 0.025 & 0.18 & 0.015 \\
\hline \multicolumn{7}{|c|}{$\begin{array}{c}\text { TABLE-3 } \\
\text { MECHANICAL PROPERTIES OF STEEL CHANNEL MC150 BEFORE AND AFTER LONG TIME CORROSION }\end{array}$} \\
\hline Sample ID & $\mathrm{YS}$ & & UTS $\left(\mathrm{N} / \mathrm{mm}^{2}\right)$ & EL (\%) & & Sectional weight \\
\hline MC-150 (as rolled) & & & $410 \mathrm{~min}$. & $23 \mathrm{~min}$. & & $16.38-17.22$ \\
\hline MC-150 (rusted) & & & 370 & 13 & & 15.61 \\
\hline
\end{tabular}


the so formed delaminated layers of corrosion product is almost 1 to 2 times thicker than original metal thickness. As a whole the overall thickness of the successive corrosion product layers is almost six times of the parent metal thickness. After the removal of the already formed corrosion product layers from the surface of the long time corroded metal, replicas of pits observed on metallic zones indicating under deposit corrosion. Grouping of these pits internal as well as externally observed. Where there is an approach for the entry of external corrosion agents like water and other corrosion agents, oxidizing agents, colour changes are pronouncedly appearing on the corrosion product layers. Corrosion product layers at the metal electrolyte interface were harder when compared to the delaminated corrosion product layers. Reaction is progressing during wet corrosion process only. Even in the course of dry conditions there are any internal modifications or rearrangements occurring due to crevice corrosion. In both micro- and macroscopic studies a common feature observed is splitting of corrosion product layers in the rolling (mechanical deformation) direction. As magnetite having conducting properties, the process of corrosion continues as and when the corroded layers come in contact with water and other pollutants. Due to a process of cathodic delamination mechanism and increase in corrosion product volume, splitting in the rolling direction was also observed in micro and macro level. Actually this channel is meant for usage in heavy structural construction like roofs, cell towers and platforms for walkways at heights, stair case bases, automobile bodies, etc. But its continuous long time atmospheric corrosion without protection leads to drastic decrease in its mechanical properties by the aggravation of corrosion damage internally.

\section{CONFLICT OF INTEREST}

The authors declare that there is no conflict of interests regarding the publication of this article.

\section{REFERENCES}

1. A.A.M.T. Adikari, R.G.N. De S. Munasinghe and S. Jayatileke, Engineer, 47, 75 (2014);

https://doi.org/10.4038/engineer.v47i2.6869.
2. M. Morcillo, B. Chico, I.Díaz, H.Cano and D. de la Fuente, Corros. Sci., 77, 6 (2013);

https://doi.org/10.1016/j.corsci.2013.08.021.

3. M. Morcillo, I. De la Fuente, I. Díaz and H. Cano, Rev. Metal., 47, 426 (2011); https://doi.org/10.3989/revmetalm.1125.

4. C. Rémazeilles and P. Refait, Corros. Sci., 49, 844 (2007); https://doi.org/10.1016/j.corsci.2006.06.003.

5. C. Rémazeilles and P. Refait, Corros. Sci., 50, 856 (2008); https://doi.org/10.1016/j.corsci.2007.08.017.

6. A.R. Mendoza and F. Corvo, Corros. Sci., 42, 1123 (2000); https://doi.org/10.1016/S0010-938X(99)00135-3.

7. C.H. Gao, H.N. Wang and J.X. Peng, Highways Automot. Appl., 1, 152 (2012).

8. F. Menan and G. Henaff, Int. J. Fatigue, 31, 1684 (2009); https://doi.org/10.1016/j.ijfatigue.2009.02.033.

9. Q. Wu and Y. Yuan, Experimental Study on Degradation Law of Mechanical Properties of Corroded Steel Bar, China Civil Engineering Society, 4, pp. 42-46 (2008).

10. P. Chotickai and M.D. Bowman, J. Bridge Eng., 11, 71 (2006); https://doi.org/10.1061/(ASCE)1084-0702(2006)11:1(71).

11. L. Balsamo, R. Betti and H. Beigi, J. Sound Vibrat., 333, 4526 (2014); https://doi.org/10.1016/j.jsv.2014.04.062.

12. X.W. Ye, Y.Q. Ni, K.Y. Wong and J.M. Ko, Eng. Struct., 45, 166 (2012); https://doi.org/10.1016/j.engstruct.2012.06.016.

13. H. Xu, Fatigue Strength, Higher Education Press (1988).

14. J. Cairns, G.A. Plizzari, Y. Du, D.W. Law and C. Franzoni, ACI Mater. J., 102, 256 (2005).

15. W. Liu, W. Li and Q. Ma, HVM Prestress. Technol., 2, 34 (2001).

16. F. Li, Y. Yuan, J. Du and H. Ma, J. Southeast Univ., 39, 340 (2009).

17. Y. Zheng, Y. Ou and L. An, Mod. Transp. Technol., 2, 33 (2005).

18. S.C. Barton, G.W. Vermaas, P.F. Duby, A.C. West and R. Betti, J. Mater. Civ. Eng., 12, 33 (2000); https://doi.org/10.1061/(ASCE)0899-1561(2000)12:1(33).

19. S.-I. Nakamura, K. Suzumura and T. Tarui, Struct. Eng. Int., 14, 50 (2004); https://doi.org/10.2749/101686604777964305.

20. S. Nakamura and K. Suzumura, J. Construct. Steel Res., 65, 269 (2009); https://doi.org/10.1016/j.jcsr.2008.03.022.

21. F. Xu, Y. Chen, X. Zheng, R. Ma and H. Tian, Materials, 12, 753 (2019); https://doi.org/10.3390/ma12050753.

22. W.J. Yang, P. Yang, X.M. Li and W.L. Feng, Mater. Corros., 63, 401 (2012); https://doi.org/10.1002/maco.201005921.

23. S. Wu, H. Chen, H.L. Ramandi, P.C. Hagan, A. Crosky and S. Saydam, Corros. Sci., 132, 234 (2018);

https://doi.org/10.1016/j.corsci.2017.12.014. 